\title{
Y 型ゼオライト触媒によるベンジルアルコールの酸化
}

\author{
（1972 年 11 月 1 日 受 理）
}

高 津 晴 義・藤 井 修治*

遷移金属にみられるような酸化還元作用のないカチオンをもつゼオライト触媒 ( $\mathrm{NaY}, \mathrm{CaY}, \mathrm{HY}$ ) を使用し，ベンジルアルコールの気相酸化を行なった。また NaY 触媒の場合については速度論的検討 も合わせて行なった。

ベンジルアルコールは NaY 触媒によりベンズアルデヒドを経て安息香酸へと逐次的に酸化されるこ とが明らかになった。ベンジルアルコールからベンズアルデヒドへの反応の反応次数はベンジルアルコ ールに対して 0.4 次であり，酸素に対して 0.5 次であった。また活性化ェネルギーは $220 \sim 300^{\circ} \mathrm{C}$ の 温度範囲で $11 \mathrm{kcal} / \mathrm{mol}$ であった。

酸化反応への転化率 (ベンズアルデヒド生成率+安息香酸生成率 $+1 / 7$ 二酸化炭素生成率) が $3 \%$ に 達する反応温度が $\mathrm{HY}$ で $195^{\circ} \mathrm{C}, \mathrm{CaY}$ で $245^{\circ} \mathrm{C}, \mathrm{NaY}$ で $265^{\circ} \mathrm{C}$ であることから 型ゼオライトの 酸化活性の強さは， $\mathrm{HY}>\mathrm{CaY}>\mathrm{NaY}$ の順序であることが明らかとなった。また二酸化炭素収率は 140 $\sim 300^{\circ} \mathrm{C}$ の温度範囲では最高 $0.43 \%$ であり，きわめて少なく良好な結果であった。

\section{1 緒咅}

合成ゼオライトは各種の有機反応に用いられて拉り，とくにそ の固体酸としての特性を利用した研究が数多くなされている。最 近，ゼオライト触媒の酸化活性が注目され，ゼオライト触媒を酸

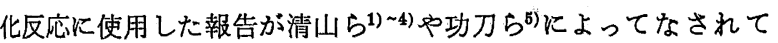
特り，また ESR の研究(7) によってその酸化活性点についても検 討されている。これらの研究はいずれすゼオライト上の遷移金属 イオンの酸化力に着目したものである。一方, Stone らは などよる各種へキサンの酸化を報告して括り，ゼオライト上の $\mathrm{Na}^{+}$イオンがへキサンの酸化に対して触媒効果をすっているこ とを示している。これらのゼオライト触媒による気相酸化に関す る研究に执いては二酸化炭素が主生成物であり，上に述べた功刀 $5^{5)}$ の水蒸気存在下に拈けるプロピレンの酸化の研究を除いて は，中間生成物は二酸化炭素とくらべて非常に少ない。

著者らは遷移金属にみられるよらな酸化還元作用のないカチオ ンをるつゼオライト触媒に注目し, 中間生成物を比較的多量に得

* 早稲田大学理工学部応用化学科, 東京都新宿区西大久保

1) I. Mochida, S. Hayata, A. Kato, T. Seiyama, J. Catal., 15, 314 (1969).

2) I. Mochida, S. Hayata, A. Kato, T.Seiyama, ibid., 19 405(1970).

3) I. Mochida, S. Hayata, A. Kato, T.Seiyama, ibid., 23, 31 (1971).

4) I. Mochida, S. Hayata, A. Kato, T. Seiyama, Bull. Chem. Soc. Jap., 44, 2282(1971).

5）久保俊彦，能田文雄，冨井博夫，功刀泰碩，日化，1972, 1621.

6) C. M. Naccache, Y.B. Taarit, J.Catal., 22, 171(1971).

7) J. T. Richardson, ibid., 9, 172(1967).

8) A. L. Agudo, F. R. Badcok, F. S. Stone, Proc. Intern. Congr. Catal. 4 th Moscow, No. 59 (1968).
るような部分酸化反応について，ぜオライト触媒の酸化活性を調 ベた。今回は $\mathrm{NaY}, \mathrm{CaY}, \mathrm{HY}$ によるベンジルアルコールの酸 化反応を取り扱い，とくに NaY 触媒においては速度論的取り扱 いを試みた。

\section{2 実験}

\section{1 触媒および試料}

反応に使用したゼオライト触媒は $\mathrm{NaY}, \mathrm{CaY}$ および HY で ある。NaY は市販の UCC 製モレキュラーシーブ SK-40 を酢酸 ナトリウム溶液に浸漬し不純物を取り除き，希アルカリ性溶液

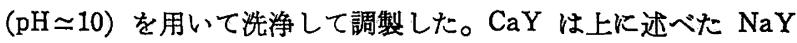
を㼍酸カルシウム溶液でイオン交換して調製し，HY は塩化アン モニウム溶液でイオン交換し，洰過洗浄後 $350^{\circ} \mathrm{C} て ゙ ~ 1.5$ 時間脱 ンモニアして調製した。CaY，HY のイオン交換率はそれぞれ 97\%，92\% であった。触媒は成型後 8〜14 メッシュの粒度にと とのえ反応に使用した。

また、ベンジルアルコールは市肘特級品を蒸留したのち反応に 用いた。

\section{2 実験方法}

実験には固定床式常压流通法装置を使用した。ベンジルアルコ ールはマイクロフィーダーにより一定速度で反応系に注入し，酸 素持よび窒素はボンベから塩化カルシウムの入った乾燥管を通し て送入した。触媒層の上部には予熱層および気化層としてグラス ウールを充テンした。触媒は反応管中で乾燥空気を送りながら $350^{\circ} \mathrm{C}$ で 1.5 時間焼成したのち反応に使用した。

二酸化岸素以外の反応生成物は氷冷和よびアセトン吸収により トラップしたのち，ガスクロマトグラフ（カラム：25\% Silicone DC 550 on Shimalite) で分析した。また二酸化炭素および酸素 は充テン剤としてシリカゲルとモレキュラーシーブ $5 \mathrm{~A}$ を用い中 間セル方式によりガスクロマトグラフで分析した。 


\section{3 結果および考察}

\section{$3.1 \mathrm{NaY}$ 触媒によるベンジルアルコールの酸化}

3.1.1 NaY の触媒活性：NaY 触媒を用いて反応を行なった 場合の反応温度の影響を図 1 に示す。ベンジルアルコール転化率 は $220^{\circ} \mathrm{C}$ で $1.4 \%$ であり，反応温度とともに増加し $300^{\circ} \mathrm{C}$ では $5.5 \%$ となった。一方，ベンズアルデヒド収率は $240^{\circ} \mathrm{C} て ゙$ 最高収 率 $1.51 \%$ を示し，その後減少した。これに対し安息香酸収率は ベンジルアルコール転化率と同様に反応温度とともに増加する傾 向を示すが，とくにベンズアルデヒド収率が減少する付近で増加

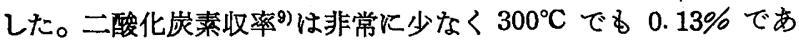
った。なお反応生成物としてこの他にコン跡程度のベンジルエー テルが生成した。一方, 触媒の活性劣化は $300^{\circ} \mathrm{C} て ゙ ~ 1.5$ 時間の使 用にさいして見られなかった。

触媒を使用しない場合，本反応は $300^{\circ} \mathrm{C}$ 以下ではまったく起こ らず，この実験条件では均一反応は無視できることが明らかとな った。また，酸素なしで反応を行なったところペンズアルデヒド がほとんど生成しなかったことから，脱水素反応す起こっていな いことがわかった。以上のことから，本反応は不均一酸化反応で あると考えることができる。

3.1 .2 ベンジルアルコールの酸化反応機構 : $220^{\circ} \mathrm{C}$ におる $W / F$ による変化を図 2 に示す。これによるとペンズアルデヒド 収率は $W / F$ の增加とともに上昇し, $W / F=2.5 \times 10^{4} \mathrm{~g}$-cat $/ \mathrm{mol}$ ・ $\mathrm{sec}^{-1}$ で最大值 $1.93 \%$ を示し，以後減少した。安息香酸収率は W/F の増加とともにゆっくりと増加し, ベンズアルデヒド収率 が最大となる付近から急に増加する傾向を示した。図 2 の微分形 から，ベンズアルデヒドおよび安息香酸生成速度を求め，その $W / F$ による変化を図 3 に示す。ベンズアルデヒド生成速度は $W / F=0$ で $4.6 \times 10^{-8} \mathrm{~mol} / \mathrm{sec} \cdot \mathrm{g}-\mathrm{cat}$ を示し, 以後直線的に減少 し, 一方; 安息香酸の生成速度は $W / F \rightarrow 0$ にしたがい0に近つ” いた。またベンズアルデヒド収率と安息香酸収率との比を求める と, この値は $W / F$ の増加にともない 0 に近づくことが明らかに

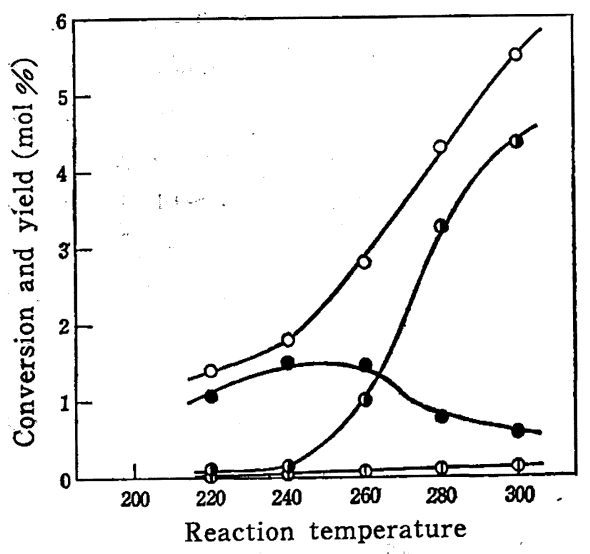

Fig. 1 Effect of reaction temperature Cat. : NaY, $W / F: 3.6 \times 10^{9} \mathrm{~g}-\mathrm{cat} / \mathrm{mol}^{-\mathrm{sec}^{-1}}$ $P_{\mathrm{B}}: 0.030 \mathrm{~atm}, P_{\mathrm{O}}: 0.20 \mathrm{~atm}$

$O$ : Conversion of benzyl alcohol

: Yield of benzaldehyde

(1) : Yield of benzoic acid

(1) : Yield of carbon dioxide

9） $1 / 7$ 二酸化炭素収率.
なった。以上のことから，本反応は

$$
\mathrm{C}_{6} \mathrm{H}_{5} \mathrm{CH}_{2} \mathrm{OH} \stackrel{k}{\longrightarrow} \mathrm{C}_{6} \mathrm{H}_{5} \mathrm{CHO} \stackrel{k^{\prime}}{\longrightarrow} \mathrm{C}_{6} \mathrm{H}_{5} \mathrm{COOH}
$$

といら逐次反応であると考えることができる。このことは上に述 べた反応温度の影響（図1）からも支持される。

3.1.3 速度論的検討：上に述べた逐次反応をもとに本反応の 速度論的な取り扱いを試みた。一般的にアルデヒドはアルコール よりも活性が大であり，ベンズアルデヒドから安息香酸への反応 は NaY なしでも起こる可能性があるので，この反応は取り扱い が困難であるため，本報ではベンジルアルコールからベンズアル デヒドへの反応について取り报った。上に述べたように安息香酸 および少量の二酸化炭素はベンズアルデヒドを経て逐次的に生成 したと考えられるので, ヘンンジアルデヒド生成量としては, これ らの量を補正した值を使用した。またこの酸化の速度論的検討は つぎの関係式に基づいて行なった。

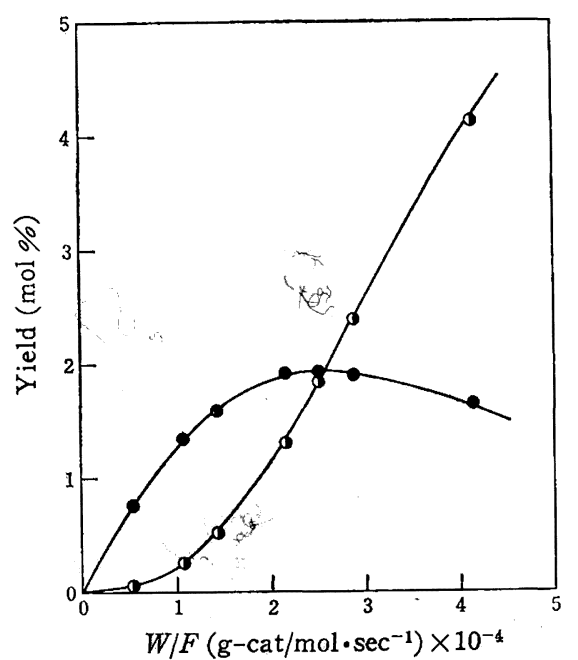

Fig. 2 Effect of $W / F$

Reaction temp. : $220^{\circ} \mathrm{C}$ $P_{\mathrm{B}}: 0.030 \mathrm{~atm}, P_{\mathrm{O}}: 0.030 \mathrm{~atm}$ $:$ Yield of benzaldehyde (1) Yield of benzoic acid

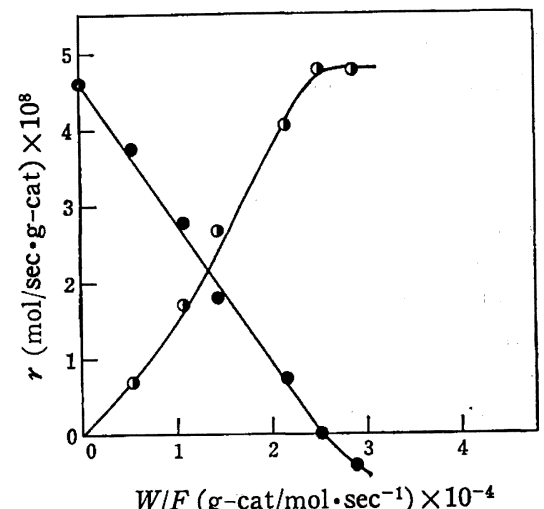

Fig. 3 Reaction rate vs. $W / F$ Reaction temp. : $220^{\circ} \mathrm{C}$ $P_{\mathrm{B}}: 0.030 \mathrm{~atm}, P_{\mathrm{O}}: 0.030 \mathrm{~atm}$ : Rate of benzaldehyde formation (1) : Rate of benzoic acid formation 


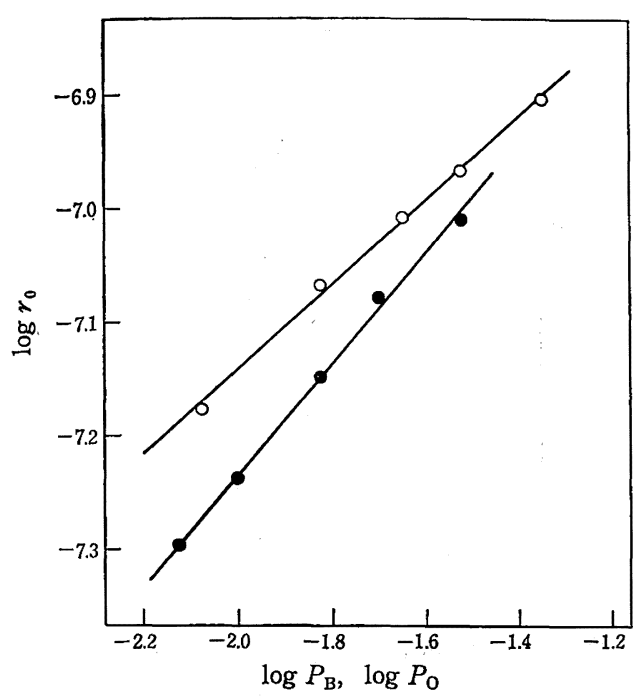

Fig. $4 \log r_{0}$ vs. $\log P_{\mathrm{B}}$ and $\log P_{\mathrm{O}}$ Reaction temp. : $220^{\circ} \mathrm{C}$

$\mathrm{O}: \log r_{0}$ vs. $\log P_{\mathrm{B}}\left(P_{\mathrm{O}}=0.20 \mathrm{~atm}\right)$

$: \log r_{0}$ vs. $\log P_{\mathrm{O}}\left(P_{\mathrm{B}}=0.20 \mathrm{~atm}\right)$

$$
r=\frac{\mathrm{d} x}{\mathrm{~d}(W / F)}=k P_{\mathrm{B}}{ }^{a} P_{\mathrm{O}}{ }^{b}
$$

ここで $\quad r$ :ベンズアルデヒド生成速度 (mol/sec·g-cat)

$x$ : ヘンズフルデヒド生成率十安息香酸生成率 $+1 / 7$ ・ 二酸化炭素生成率

$W:$ 触媒量 $(\mathrm{g})$

$F:$ 総原料送入速度 $(\mathrm{mol} / \mathrm{sec})$

$k$ : 反応速度定数 $(\mathrm{mol} / \mathrm{sec} \cdot \mathrm{g}-\mathrm{cat})$

$P_{\mathrm{B}}:$ ベンジルルコール分圧

$P_{0}:$ 酸案分圧

$a, b:$ 定数

初速度 $r_{0}$ の $P_{\mathrm{B}}$ による変化を $P_{\mathrm{O}}$ が一定とみなせる酸素過剩 のもとで，しかも反応生成物の分圧が無視できるような転化率の

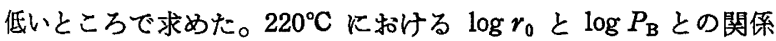
を図4 亿示す。この図の直線の傾さから，本反応はベンジルアル コールに対して 0.4 次であることが求められた。同様に $P_{\mathrm{B}}$ が 一定とみなせるようなベンジルアルコール過剩のもとで $r_{0}$ の $P_{0}$ による変化（図 4 ）を求め, 本反応が酸素に対して 0.5 次である ことが明らかになり，このことから酸素は $\mathrm{NaY}$ 上に解離した形

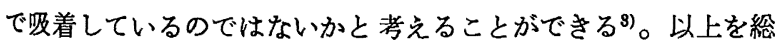
合すると，本反応は $r=P_{\mathrm{B}}{ }^{0.4} P_{0}{ }^{0.5}$ にしたがうことが明らかとな った。

以上の実験結果からベンズアルデヒド生成の反応速度定数 $k$ を 求め表 1に示した。またその Arrhenius プロット（図 5 ）の直 線の傾さから $220 \sim 300^{\circ} \mathrm{C}$ の温度範囲でベンズアルデヒド生成の 活性化エネルギーを求めたところ $11 \mathrm{kcal} / \mathrm{mol}$ となり，金属酸化 物触媒によるアルコールの酸化(10)11 に打ける活性化エネルギー (20〜30 kcal/mol) よりはるかに小さいことが明らかとなった。

10) N. Pernicone, F. Lazzerin, G. Liberti, G. Lanzavecchia, J. Catal., 14, 293(1969).

11) T. Vrbaski, W. K. Mathews, J. Phys. Chem., 69, 457 (1965).

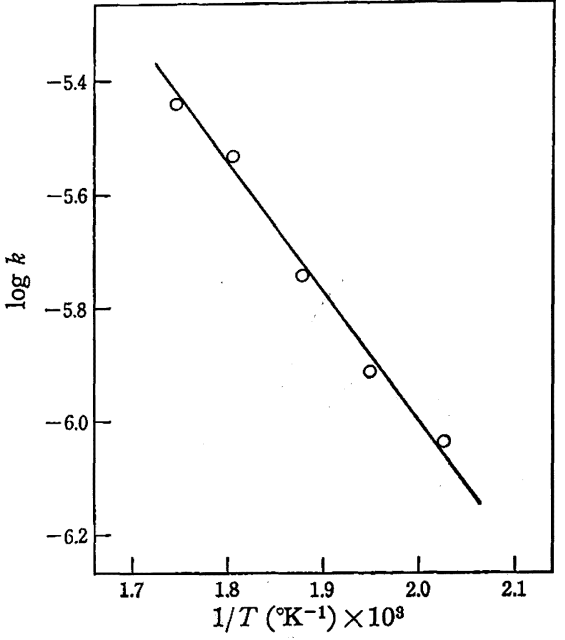

Fig. 5 Arrhenius plots for the oxidation of benzyl alcohol to benzaldehyde

Table 1 The rate constant $k$

\begin{tabular}{|c|c|c|c|c|c|}
\hline $\begin{array}{l}\text { Reaction temp. } \\
\left({ }^{\circ} \mathrm{C}\right)\end{array}$ & 220 & 240 & 260 & 280 & 300 \\
\hline $\begin{array}{c}k \\
(\mathrm{~mol} / \mathrm{sec} \cdot \mathrm{g}-\mathrm{cat})\end{array}$ & $\begin{array}{l}9.2 \times \\
10^{-7}\end{array}$ & $\begin{array}{c}1.2 \times \\
10^{-6}\end{array}$ & $\begin{array}{l}1.8 \times \\
10^{-6}\end{array}$ & $\begin{array}{l}2.9 \times \\
10^{-6}\end{array}$ & $\begin{array}{l}3.6 \times \\
10^{-6}\end{array}$ \\
\hline
\end{tabular}

以上本研究で $\mathrm{NaY}$ がペンジルアルコールの部分酸化に対して 触媒活性を有することが明らかになった。一方, Richardson ${ }^{7} や$ 清山ら ${ }^{3)}$ により遷移金属 $\mathrm{Y}$ 型ゼオライトの酸化活性は金属イオン の酸化力によるものであることが示されている。しかしながら本 研究で使用した NaY は酢酸ナトリウム溶液に十分浸漬してあ り，また希アルカリ性溶液 $(\mathrm{pH} \simeq 10)$ で注意深く洗浄したので， この NaY 触媒の酸化活性が不純物として含まれる金属イオンや 脱カチオン sites によるものであるとは考兄られない。 $\mathrm{Na}^{+}$イオ ンには遥移金属イオンのよらな酸化還元作用がないことから，本 研究で用いた NaY 触媒の活性点としては金属イオンの酸化還元 作用以外の酸化活性点をゼオライト構造中に考えざるを得ない。

3.2Y型ゼオライトのカチオンの相違による酸化活性の比較

3.2.1 CaY および HY による反応の反応温度の影響 : CaY 抌よび HY を用いた場合の反応温度の影響をそれぞれ図 6, 図 7 に示す。ヘンジルアルコール転化率はベンジルエーテルの生成の ため, 前者では $200^{\circ} \mathrm{C}$, 後者では $160^{\circ} \mathrm{C}$ 付近で極大值を示すが, 前者に执いては $260^{\circ} \mathrm{C}$ 付近からふたたび増加する。後者でも同様 に $220^{\circ} \mathrm{C}$ 以上で増加するはずであるが，触媒の炭化がいちじるし く、データを得ることはできなかった。ベンズアルデヒド収率は 反応温度とともに徐々に增加し前者では $240^{\circ} \mathrm{C}$ で最大值 $1.04 \%$ を示し, 後者では $200^{\circ} \mathrm{C}$ で最大值 $1.43 \%$ を示した。安息香酸収 率はいずれの場合も反応温度とともに增加し, 前者では $240^{\circ} \mathrm{C}$, 後者では $180^{\circ} \mathrm{C}$ 付近から急激に增加し始め, それぞれ $280^{\circ} \mathrm{C}$, $200^{\circ} \mathrm{C}$ で 7.18\%，2.81\% に達した。ベンジルアルコールの脱水 反応によって生成するベンジルエーテルの収率衫は前者では $200^{\circ} \mathrm{C}$ で，後者では $160^{\circ} \mathrm{C}$ でそれぞれ最大值 $4.50 \% ， 11.2 \%$ を 示し以後急激に減少した。トルェン収率は前者では $220^{\circ} \mathrm{C} て ゙$ 最大 値をるつゆるやかな増加減少曲線を描き，後者では $200^{\circ} \mathrm{C}$ まで徐 々に増加した。

12）2-ペンジルェーテル生成率. 


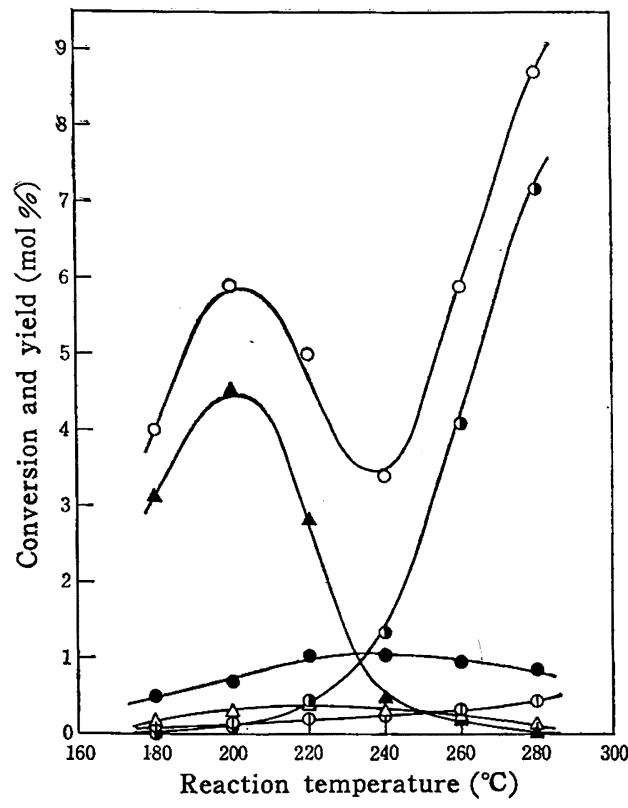

Fig. 6 Effect of reaction temperature

Cat. : CaY, $W / F: 3.6 \times 10^{3} \mathrm{~g}-\mathrm{cat} / \mathrm{mol} \cdot \mathrm{sec}^{-1}$

$P_{\mathrm{B}}: 0.030 \mathrm{~atm}, P_{\mathrm{O}}: 0.20 \mathrm{~atm}$

$\mathrm{O}:$ Conversion of benzyl alcohol

: Yield of benzaldehyde

: Yield of benzoic acid

(1) : Yield of carbon dioxide

$\Delta$ : Yield of benzyl ether

$\triangle:$ Yield of toluene

3.2.2 NaY, CaY, HY の酸化活性の比較：前に述べた $\mathrm{NaY}$ 用いた場合の反応温度の影響（図 1）と $\mathrm{CaY}, \mathrm{HY}$ を用いた 場合の反応温度の影響（図 6, 図 7) から, その酸化活性の比較 を行なった。ベンジルアルコールの酸化反応への転化率 ${ }^{13)}$ が $3 \%$ に達する反応温度を求めると表 2 のようになり, 酸化活性は $\mathrm{HY}>\mathrm{CaY}>\mathrm{NaY}$ の順序となることがわかった。

つぎに NaY， CaY，HY の酸化触媒としての適性について考 察することにする。ベンジルエーテルはベンジルアルコールの脱 水反応により生成したものであるが， NaY の場合（図 1), この 副生成物がほとんど生成しなかったのに対し， CaY，HY の場合 (図 6, 図 7), 強い固体酸触媒として作用することからかなりの 生成がみられた。このため $\mathrm{NaY}$ の場合には $\mathrm{CaY}, \mathrm{HY}$ と比較 して酸化反応への選択率がきわめて高くなっており,この点が $\mathrm{NaY}$ 触媒の一つの特徵となっている。また $\mathrm{NaY}$ の場合, 二酸 化炭素収率も $300^{\circ} \mathrm{C}$ で $0.13 \%$ と非常に少なく, さらに触某の安

13）ヘヘンズアルデヒド生成率十安息香酸生成率 $+1 / 7$ ・酸化 炭素生成率.

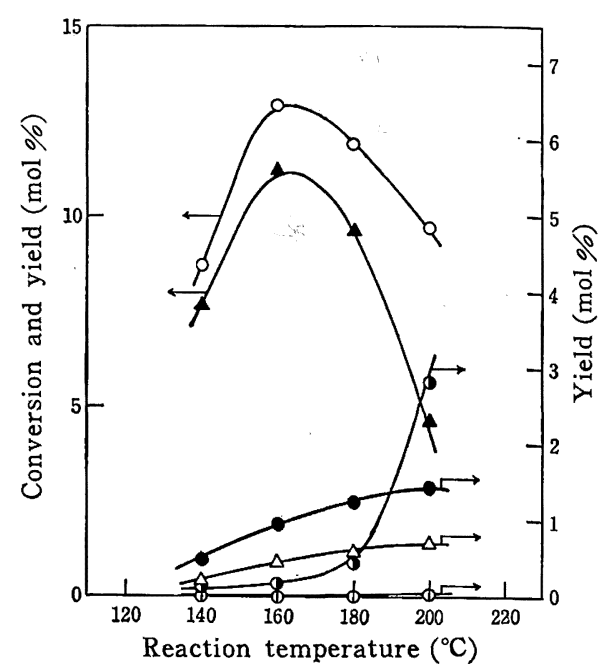

Fig. 7 Effect of reaction temperature Cat. : HY, $W / F: 3.6 \times 10^{3} \mathrm{~g}-\mathrm{cat} / \mathrm{mol} \cdot \mathrm{sec}^{-1}$ $P_{\mathrm{B}}: 0.030 \mathrm{~atm}, P_{\mathrm{O}}: 0.20 \mathrm{~atm}$

$O$ : Conversion of benzyl alcohol

: Yield of benzaldehyde

(1) : Yield of benzoic acid

(1) : Yield of carbon dioxide

$\Delta$ : Yield of benzyl ether

$\triangle:$ Yield of toluene

Table 2 The temperature where the conversion of benzyl alcohol to the oxidation reaction reached $3 \%$

\begin{tabular}{cc} 
Cat. & $\begin{array}{c}\text { Temperature } \\
\left({ }^{\circ} \mathrm{C}\right)\end{array}$ \\
\hline $\mathrm{NaY}$ & 265 \\
$\mathrm{CaY}$ & 245 \\
$\mathrm{HY}$ & 195
\end{tabular}

定性も $\mathrm{CaY}, \mathrm{HY}$ とくらべてもっともすぐれている。以上のこ とから NaY が酸化触媒としてすぐれた性質を有しているすのと 考えられる。

最後に HY と NaY の酸化活性を比較することによりゼオラ イトの酸化活性点について考察してみる。さきに NaY の酸化活 性点が不純物として含まれる金属イオンなどによるものではない ことを示した。HY が NaY よりも強い酸化活性を有することか ら, Stone ら ${ }^{8)}$ が NaX などによるへキサンの酸化反応に和いて 報告しているよらな $\mathrm{Na}^{+}$イオンの触媒効果は本反応に対しては さほど重要な役剖を演しているとは考えられない。以上のことを 総合するとゼオライトには，その pore 構造中に酸化活性を示寸 活性点が存在すると考えざるを得ない。このゼオライトの酸化活 性点に関する詳細については今後の課題である。

\section{Catalytic Oxidation of Benzyl Alcohol over $\mathrm{Y}$ Type Zeolites \\ Haruyoshi Takatsu and Shūya Fujir \\ Department of Applied Chemistry, School of Science and Engineering, Waseda University; Shinjuku-ku, Tokyo, Japan}

In order to investigate the oxidation activities of zeolites ( $\mathrm{NaY}, \mathrm{CaY}, \mathrm{HY}$ ) in which exchanged cations have no apparent oxidation-reduction ability as is seen for transition metal, the vapor phase oxidation of benzyl alcohol over these zeolites was studied. 
It was found that the oxidation proceeded consecutively over $\mathrm{NaY} ; \mathrm{C}_{6} \mathrm{H}_{5} \mathrm{CH}_{2} \mathrm{OH} \longrightarrow \mathrm{C}_{6} \mathrm{H}_{5} \mathrm{CHO}$ $\longrightarrow \mathrm{C}_{6} \mathrm{H}_{5} \mathrm{COOH}$. The reaction order of the oxidation of benzyl alcohol to benzaldehyde was 0.4 with respect to benzyl alcohol and was 0.5 with respect to oxygen. The activation energy in the temperature range of $220 \sim 300^{\circ} \mathrm{C}$ was $11 \mathrm{kcal} / \mathrm{mol}$.

The temperatures where the conversion of benzyl alcohol reached $3 \%$ were as follows; HY: $195^{\circ} \mathrm{C}, \mathrm{CaY}: 245^{\circ} \mathrm{C}, \mathrm{NaY}: 265^{\circ} \mathrm{C}$. Therefore, the order of oxidation activity was $\mathrm{HY}>\mathrm{CaY}>$ $\mathrm{NaY}$. The yield of carbon dioxide was very low $(<0.43 \%)$.

\title{
炭化チタン付ニッケル触媒上でのアセトン水素化における イソブチルメチルケトンの生成
}

(1972 年 12 月 4 日 受 理)

\author{
岡田 正秀・浅見 幸雄・渡辺 文 雄*
}

窒素中（I）および空気中（II）焼成後水素還元した量論的炭化チタン担持ニッケル触媒の $150^{\circ} \mathrm{C} に$ おけるアセトン水素化特性を調べた。

Iでは多量の 2-プロパノールとわずかのインブチルメチルケトンを生成したのに対し，IIでは少量 のアルコールとともにケトンを優勢に生じた。X線分析により，Iでは金属ニッケルと量論的炭化チタ ンのほかにいくらか酸化ニッケルの，Iでは上記種以外にいくらか二酸化チタン（ルチル型）の存在す ることが知られた。炭化チタン付酸化ニッケル（III）抢よびルチル付ニッケル（N）はどららも両液状 生成物の生成に対していくらか活性を示すことがわかった。主生成物は而ではアルコール，Nではケト ンであった。無担体ニッケル上では反応生成物中にケトンは存在しなかった。

それゆ完実験結果から, 酸化ニッケルを含むまたは含まないニッケルと二酸化チタンを含むまたは含 まない炭化チタンを組み合わせた触媒系がアセトンの水素化において 2-プロパノールとイソブチルメ チルケトンの同時生成をもたらしたと結論される。

\section{1 緒言}

近年, 透移金属の炭化物 $\left(\mathrm{Cr}_{3} \mathrm{C}_{6}, \mathrm{Cr}_{7} \mathrm{C}_{3}, \mathrm{Cr}_{3} \mathrm{C}_{2}, \mathrm{TiC}, \mathrm{WC}\right)$, ケ化物 $\left(\mathrm{Cr}_{3} \mathrm{Si}_{1}, \mathrm{Cr}_{5} \mathrm{Si}_{3}, \mathrm{CrSi}_{2}, \mathrm{MoSi}_{2}, \mathrm{Mo}_{3} \mathrm{Si}, \mathrm{V}_{3} \mathrm{Si}, \mathrm{ReSi}\right)$, 窒化物 $\left(\mathrm{CrN}, \mathrm{Cr}_{2} \mathrm{~N}\right)$ なと， いわ功る高融点化合物の触媒的性質 についていくつか報告が出されていて，それらの多くは主として 脱水素触媒としての機能に焦点が拁かれている1)。著者の研究室 に拈いても最近セメンタイト $\left(\mathrm{Fe}_{3} \mathrm{C}\right)$ がエチルベンゼンの脱水素 以活性をもつことを観測したし2)，さらにまた代表的な遷移金属

* 熊本大学工学部合成化学教室, 熊本市黒髮

1）たと党ば, L. Yu. Tazhunkhuei, S.Z. Roginskii, G.V. Samsonov, M. I. Yanovskii, Neftekhimiya, 3, 843(1963); K. M. Gitis, V. L. Polinin, G. V. Samsonov, T. Ya. Kosolapova, M. I. Rozengart, "Scientific selection of Catalysts", ed. by A. A. Balandin et al., Israel Program for Scientific Translations Ltd., Jerusalem (1968) p. 256 ; G. V. Samsonov, T. G. Bulankova, P. A. Khodak, E. M. Prshedromirskaya, V. S. Sinelnikova, V. M. Sleptov, Kinet.Katal., 10, 1057(1969).

2）岡田正秀，浅見幸雄，草野哲二，日化，1972，518.
の炭化物・窒化物の脱水素触媒作用について分子論的説明を加 兄，これらの化合物が電子受容体として反応物質の水素引き拔き に寄与することを明らかにしだ)。

一方，チタン岸化物と金属ニッケルを組み合わせた触媒系のエ タン水素化分解能を調べた結果が昨年報告されたむ)。これは量論 比の異なるチタン炭化物ーニッケル間の笔子相互作用飞基つくく触 媒能の変化汇注目した点で興咮があるとい兄る。この種の触媒系 の研究は類例が少なく、検討の価値があるう。

本研究はこれと同一触媒系ではあるが，担体の炭化チタンとし て量論化合物を用い，母触媒の前処理条件のいかんによってはあ るいは起こりらるかもしれない触媒能の变化を予想して行なった るのである。モデル反応にはアセトンの水素化を選んだ。その理 由恃水素化以外涚水縮合なぞの副反応の生起が期待され，生成 物組成の変化を調べるらえに好適と考えたからである。

3) K. Ohkubo, H. Shimada., M. Okada, Bull. Chem. Soc. Jap., 45, 3475(1972).

4) L. A. Maddox, H. F. Rase, Ind. Eng. Chem, Prod. Res. Develop., 10, 32(1971). 